\title{
"Home" and the Narrative of an Impossible Nostos
}

\section{Eleonora Rao}

\section{(2) OpenEdition}

1 Journals

Electronic version

URL: https://journals.openedition.org/ces/5009

DOI: 10.4000/ces.5009

ISSN: 2534-6695

\section{Publisher}

SEPC (Société d'études des pays du Commonwealth)

\section{Printed version}

Date of publication: 1 April 2015

Number of pages: $27-34$

ISSN: 2270-0633

\section{Electronic reference}

Eleonora Rao, "'Home" and the Narrative of an Impossible Nostos", Commonwealth Essays and Studies [Online], 37.2 | 2015, Online since 13 April 2021, connection on 17 July 2021. URL: http:// journals.openedition.org/ces/5009 ; DOI: https://doi.org/10.4000/ces.5009

\section{(c) (i) (9)}

Commonwealth Essays and Studies is licensed under a Licence Creative Commons Attribution - Pas d'Utilisation Commerciale - Pas de Modification 4.0 International. 


\section{"Home" and the Narrative of an Impossible Nostos}

The article looks at the contradictory dynamics at work in the representation of a "homecoming" in Alice Munro's story "Home." It discusses the protagonist's changed relation to place and landscape as she returns to her former home as an adult. The house she lived in as a child has been renovated and is almost entirely transformed now. Her reflections suggest loss and nostalgia; it is however a nostalgia of a reflective kind which does not pretend to rebuild the mythical place called home; it does not indulge in loss. Instead it is ironic, inconclusive and fragmentary.

Representations of the narrator as an eccentric outsider who experiences feelings of nostalgia, shame and denial are frequent in Alice Munro's texts. This essay, which focuses on the short story "Home" from the collection The View from Castle Rock (2006), looks at the dynamics of "being home" and "not being home" at play in the text, as theorized by Biddy Martin and Chandra Mohanty in their essay "Feminist Politics: What's Home Got to Do with It?" (1986). Here the authors show how this oscillation engenders longing as well as contempt. In this short story, "home" is constructed as a site of refuge and comfort that exists mainly at the level of memory, and progressively shifts to become a site of conflict, shame and denial, in a way that is reminiscent of Munro's short story cycle Who Do you Think You Are? (1978). Likewise one notices an oscillation in the narrative between "restorative nostalgia" and "reflective nostalgia" - a distinction elaborated by Svetlana Boym:

Reflective nostalgia is more concerned with historical and individual time, with the irrevocability of the past and human finitude. Re-flection suggests new flexibility, not the reestablishment of stasis. The focus here is not on recovery of what is perceived to be an absolute truth but on the meditation on history and passage of time. [...] Restorative nostalgia evokes national past and future; reflective nostalgia is more about the individual and cultural memory. [Restorative nostalgia] ends up reconstructing emblems and rituals of home and homeland in an attempt to conquer and spatialize time. Reflective nostalgia cherishes fragments of memory and temporalizes space. (49)

"Home" starts with a journey involving three bus rides and includes a detailed description of the social and geophysical scenario of the multicultural Canada the narrator encounters: "This is an area with a heavy population of German and Dutch settlers, and some of the older people are speaking in one or another of those languages" (The View 285). The narrator is obviously attached to this landscape. As critics have emphasized, Munro is very much aware of the intimate connection between person and place. Robert McGill in particular has devoted special attention to the role of place and landscape in Munro's texts, where, he argues, "space is not subordinate to characters but interconnected with them" ("Distance" 106; see also "Open Houses"). This is not, however, a "homecoming." The narrator's familiarity with the place and with the house she grew up in is almost immediately both pointed at and undermined. A hint of nostalgia surfaces at the beginning of the story:

Now that I am living only a hundred miles away I come home every couple of months or so. Before this, for a long time, I lived more than a thousand miles away and would 
go for years without seeing this house. I thought of it then as a place I might never see again and I was greatly moved by the memory of it. I would walk through its rooms in my mind. (288)

At the time of the narration, however, her feelings have changed. As Catlin Charman remarks, "now that she has returned, she sees the family home, and the changes it has undergone, with a more critical, less distorted lens" (264). What happens next, the narrator's reaction to a changed scenario, is unexpected. The narrator minutely observes and describes the significant renovations made by her father, thus suggesting feelings of yearning for what is lost:

In my mind, when I was far away, I would also see the kitchen ceiling, made of narrow, smoke-stained, tongue-in-groove boards, and the frame of the kitchen window gnawed by some $\operatorname{dog}[\ldots]$. The wallpaper was palely splotched by a leaking chimney, and the linoleum was repainted by my mother every spring, as long as she was able. [...]

That ceiling is hidden now behind squares of white tiles, and a new metal window frame has replaced the gnawed wooden one. The window glass is new as well [...].

Even the outside of the house, the red brick whose crumbling mortar was particularly penetrable by an east wind, is going to be covered up with while metal siding. [...] So it seems that this peculiar house - the kitchen part of it built in the eighteen-sixties - can be dissolved, in a way, and lost, inside an ordinary comfortable house of the present time. (288-9)

This detailed description of the house as it was before and as it is at the time of the narration, is minute, almost obsessive: "and there is light everywhere - ceiling lights and plug-in lights, long blazing tubes and hundred-watt bulbs" (289). Just after experiencing this longing for the past, she admits to herself that her feelings for this house have changed with time: "I do not lament this loss as I would once have done" (289). The narrator's perception, her view of the renovated house, does not lead to nostalgia. It is a gaze that defamiliarizes what was once very well known. One of the consequences of defamiliarization or estrangement is that it forces one to think of home, in different, often more complex terms. When the familiar is defamiliarized or estranged, it can no longer be taken for granted.

Although Shklovsky coined the term "defamiliarization" to mark a distinction between poetic language and practical, communicative language, in later years he argued it applied to all art, which ideally would force the viewer/reader to perceive the subject in a new way, outside habitualization. Here, in a well-known passage from Theory of Prose he stresses the vital importance of working against habitualization, also known and translated as "automatization":

Held accountable for nothing, life fades into nothingness. Automatization eats away at things, at clothes, at furniture, at our wives, and at our fear of war. [...] And so, in order to return sensation to our limbs, in order to make us feel objects, to make a stone feel stony, man has been given the tool of art. The purpose of art, then, is to lead us to a knowledge of a thing through the organ of sight instead of recognition. By "estranging" objects and complicating form, the device of art makes perception long and "laborious." The perceptual process in art has a purpose all its own and ought to be extended to its fullest. (5-6)

In "Home," the narrator recalls how, during her first visit to her father's house after her marriage and her move east, she had a disquieting dream. Uncanny feelings arise when something familiar (a house, a family member), starts to act a bit strange; as Freud explains it in the famous 1919 essay "Das Unheimliche," "Death and the re- 
animation of the dead are typically represented as uncanny themes" (153). The dream evokes a Freudian atmosphere of uncanniness as the narrator dreams she encounters her dead mother in what was once the master bedroom (but is now assigned to her). Her father has already remarried and Irlma, his second wife, is about to redecorate that room and paint it in blue and white. In the dream, the narrator finds her mother busy "painting the baseboards yellow" in order to prevent Irlma from painting the room (The View 309). The narrator ends her account of the dream by remarking that her mother was very much like her old self: "And that was exactly like her, in the old days" (309). The house and the room, however, are perceived by the narrator as alien and unfamiliar.

Other scenes that go beyond received and conventional notions of reality are evoked at the end of the story. Defamiliarization causes notions of home and belonging to be reconsidered:

[...] I feel obliged to hide from him the fact that the house does not mean as much to me as it once did, and that it really does not matter to me now how he changes it.

I know how you love this place,' he says to me, apologetically yet with satisfaction. And I don't tell him that I am not sure now whether I love any place, and that it seems to me it was myself that I loved here - some self that I have finished with, and none too soon. (290)

Dynamics of "being home" and "not being home" soon surface in the text and cause longing, as well as, contempt. Home, initially constructed as a site of refuge and safety, progressively metamorphoses into a site of conflict, shame and finally denial. Often in her fiction, Munro shows a character gaining consciousness of the false comfort that home provides. The idea that home is a site of bounded safety is undermined and home, on the contrary, is shown to be very precarious, fragile, and ultimately illusionary, as in the following passage from "Royal Beatings" (Who Do You Think You Are?): "And just as there is a moment, when you are drugged, in which you feel perfectly safe, sure, unreachable, and then without warning and right next to it, there is a moment in which you know the whole protection has fatally cracked, though it is still pretending to hold soundly together" (Who 25). Lorna Hutchinson has effectively captured and summed up many of the qualities of Munro's writing, especially the way in which it deals with different spheres what is commonly construed as "reality": "Munro deals with the intricacies of human nature and a realism that develops through the extraordinary detail of place and person amidst a mire of ambiguity" (189). In her stories, "the familiar world is inextricably linked to the unfamiliar; it exists only through its darker sphere, and vice versa" (194). It is worth emphasizing that in Munro's texts, as Robert McGill reminds us, "the realist plea is for verisimilitude [...] Munro's concept of what is 'real' is more complex than one might first suspect" ("Distance" 11). In "The Office," the feeling of being "sheltered and encumbered [...] warmed and bound" (Dance 61) in one's home, is set against moments in which the protagonist steps "out of the darkness of sheltered existence" (Arendt 51). As a result, places that have a strong emotional signification change into "derangements of anonymous space" (Yeager 10). This causes the protagonist to feel "exposed" and to have such a harsh experience of both freedom and loneliness that they become impossible to bear. A more fundamental sense of uncertainty can be found in "Images," also from Munro's début collection. Here, disorientation and insecurity are connected to the narrator's inability to recognize her own home: 
"Whose house is that?" my father said, pointing.

It was ours, I knew it after a minute. We had come round in a half-circle and there was the side of the house that nobody saw in the winter. (Dance 42)

Munro's short stories often display an obsession with "home" recurrent in narratives of displacement and dispossession. More often than not, home needs to be reimagined in the stories in order to enable a sense of belonging. In "Home," the middle-aged narrator becomes aware of the treacherous, provisional sense of security "home" gives her. As a result, her sense of belonging is shaken.

Critical theory has problematized the notion of "home." As Rose Marangoly suggests, "Home is also the imagined location that can be more readily fixed in a mental landscape than in actual geography" (11). Edward Said has written extensively on the subject of place, home, and homeland and the numerous implications of these terms: "But this idea of place does not cover the nuances, principally of reassurances, fitness, belonging, association, and community, entailed in the phrase at home or in place" (World 8). In "Family Furnishing," from the 2001 collection, Hateship, Friendship, Courtship, Loveship, Marriage, Munro returns to the question of home as a place which fails to provide comfort and stability. Here the meaning of "home ground" as dangerous territory is twofold. On the one hand, Munro represents home as a place that at times can provide false comfort and that can be also a locus of painful conflicts. On the other hand, "home ground" in the passage that follows, refers metafictionally, as is often the case with Munro, to her own work as a writer. In this story "home ground" works against "habitualization." The narrator is compelled to "see" her life with fresh eyes. Consequently, her life as a writer, or more poignantly, her work as a writer cannot be taken for granted. The passage is worth quoting in full:

There was a danger whenever I was on home ground. It was the danger of seeing my life through other eyes than my own. Seeing it as an ever-increasing roll of words like barbed wire, intricate, bewildering, uncomforting - set against the rich productions, the food, flowers, and knitted garments, of other women's domesticity. It became harder and harder to say that it was worth the trouble. (111)

The risk is that writing itself becomes meaningless and useless when confronted with other, seemingly more productive activities. The first line in the next paragraph ends with a question, and thus provides an answer, at least for the time being: "Worth my trouble, maybe, but what about anyone else's?" (111).

In the same collection there is a story which borrows its title from a type of construction known as "Post and Beam." In the story, the house is not seen as a prison; on the contrary the protagonists seem to be very proud of it:

It was a contemporary house, built in the West Coast style called Post and Beam [...] the idea was to fit in the original forests. So the effect was plain and functional from the outside [...]. Inside, the beams were exposed and none of the wood was covered up. The fireplace $[. .$.$] was set in a stone chimney and went up to the ceiling. (195-6)$

The house does look like an ideal dwelling for its owners, and indeed the male protagonist, Brendan, is "very proud of their house" (195). But for Lorna, his wife, the place holds too many expectations and demands. When Lorna finds herself alone in her friend's bare rented room, she feels at peace and would love to stay there for hours. Inside the room she experiences a momentary, longed-for sense of relief: "What she really wanted to do was [...] to sit for hours not so much looking at this room as sinking 
into it. To stay in this room where there was nobody who knew her or wanted a thing from her" (201). The sense of peace and freedom from the demands of family members found in the room is reminiscent of Doris Lessing's 1963 story, "To Room 19." Although in Lessing's case, the protagonist's need and desire to spend time alone in the cheap and "hideous" (980) hotel room lead to a psychotic break and, ultimately, suicide.

Biddy Martin and Chandra Mohanty examine how subjects are constituted through their relationship with "home." However, they question the received notions of "home" and the atmosphere of security, safety and individualism that has come to be associated with the word. The sense of bounded comfort and protection associated with "home" has been supported by a significant amount of scholarship. As an example, one could refer to the work of human geographer Douglas Porteous:

Home provides both the individual and the small primary group known as the family with all the three territorial satisfactions [identity, security, stimulation]. These satisfactions derive from the control of physical space, and this control is secured by two major means. The personalization of space is an assertion of identity and a means of ensuring stimulation. (383)

However, even for Porteous, the idea of home as a major fixed reference point for structuring reality is problematic. Precisely because it functions as an archetypical reference point, there are other important aspects to be taken into account. First and foremost, the division of psychic space between self and non self which has generated the essential dichotomy in geographical space between home and not home (see Bachelard 1969). For Porteous and other human geographers of the 1970s, home can only be understood in terms of journeys (Lowenthal). It is likely that during the traveler's absence both home and the individual may irretrievably change. That is why homecoming is considered impossible, and the traveler, in this view, is left with longing and unassuageable regret. Porteous concludes his argument: "As psychic space, home paradoxically involves journey, the result of which may be the loss of the original home image and an infinitude of regret" (390). Martin and Mohanty take the dichotomy of home and not home much further in their deconstruction of received notions of "home":

"Being home" refers to the place where one lives within familiar, safe, protected boundaries; "not being home" is a matter of realizing that home was an illusion of coherence and safety based on the exclusion of specific histories of oppression and resistance, the repression of differences even within oneself. (191)

In "Home," as the narrator's visit turns out to be longer than expected, the protagonist experiences an eerie time warp, and a denial of her actual life and achievements as an adult:

Time and place can close in on me, it can so easily seem as if I have never got away, that I have stayed here my whole life. As if my life as an adult was some kind of dream that never took hold of me. I see myself not like Harry and Irlma, who have to some extent flourished in this life, or like my father, who has trimmed himself to it, but more like those misfits, captives - nearly useless, celibate, rusting - who should have left but didn't, couldn't, and are now unfit for any place. (312)

She describes this "vision": "I can see myself as a middle aged daughter who did her duty, stayed at home, thinking that someday her chance would come, until she woke up and knew it wouldn't" (312). Again, in this story Munro shows how home "may smother an individual who is unable to leave it for considerable periods" (Porteous 387). It 
can easily become "a trap which first encapsulates, then submerges the ego" (Porteous 387).

In the story, the protagonist, if not a social misfit, is represented nonetheless as an outsider to her own family and to the community. There is no recognition of her success as a writer in her family. For her stepmother, writing means handwriting, as the narrator soon realizes with dismay: "It took me a moment to figure out that she was talking about handwriting. That's what 'writing' has always meant around here" (291). In addition, the writing of fiction is considered an activity with no use or purpose, defined as "making things up" (291).

A paradox lying at the core of Munro's texts emerges for her characters: on the one hand, an obsession with place and home, or home-place, which suggests a need for security and safety; on the other hand, the impossibility of achieving a sense of belonging to a place or to a community. In a review of The View from Castle Rock, Munro is cited saying: "When you write about real people you are always up and against contradictions" (Mars-Jones n.p.). The reviewer then observes, "fiction thrives on contradictions. Life, though, is amateurish in its shaping. More fates fizzle than explode. [...] Munro's filling of the gaps is lovely in itself, but keeps bumping up against the implacability of the record" (Mars-Jones n.p.). Sometimes Munro's characters escape from home and manage to dodge conventions and traditions. A very significant escape occurs in "Wild Swans" (from Who Do You Think You Are?): the train journey of the young female protagonist to Toronto, away from her provincial home town, could be seen as a first "line of flight" that provides the exhilarating sense of a multitude of possibilities to be explored. The train that takes Rose elsewhere becomes a pathway, a liminal space between, first of all, class and cultural differences: her working-class background, which she rejects, and the upper-middle-class setting she will eventually get to know. Rose is unaware at this stage of the invisible boundaries of class and cultural difference she is crossing. It is, however, thanks to those in-between places - those boundaries, and the act of trespassing them - that the movement towards a not-yet-known beyond begins. Rose's journey could be seen as following the trajectory of a Deleuzian line of flight in the sense that it has within it Rose's unsaid: the not-yet-articulated aspirations and desires. The line of flight is a moment, in Deleuze's terms, of deterritorialization - that is "the moment by which one leaves the territory" (559). In this respect, Rose's trip on that train becomes an escape route - "out of the cage of codification - codification of social practices, rules of behavior and modes of thought" (West-Pavlov 202). From now on, there won't be any real homecoming. The gap between Rose's supposed "home place" and the locations of her successive re-settlements will widen to a point of no return:

Rose was going to Toronto on the train for the first time by herself. [...] She had a window seat, and was soon extraordinarily happy. She felt Flo receding, West Hanratty flying away from her, her own wearying self discarded as easily as everything else. She loved the towns less and less known. (Who 76-7)

In Who Do You Think You Are? a pervasive sense of precariousness envelops the narrator's perception of her world. She is represented as an eccentric, and is aware of being perceived as such. Such a nomadic existence has as its counterpart a sense of insecurity as she is at the mercy of unpredictable encounters and of risks. Nevertheless, there is something to be gained from this condition. As Edward Said has notably argued in a well-known essay: 
Even if one is not an actual immigrant or expatriate, it is still possible to think as one [...] and always to move away from centralized authorities towards the margins, where you see things that are usually lost on minds that have never traveled beyond the conventional and the comfortable. (Representations 63)

Eventually, towards the end of this short story cycle, there will be a more positive note: the sense of shame that has accompanied Rose will lift and there will be room for creativity (See Rao).

Dynamics of class and cultural difference are at play also in "The Ticket," the story that precedes "Home" in The View from Castle Rock. Here the narrator's wedding is approaching and the entire household bristles with preparations. Two trunks are filled with presents from her own family members: linen, towels, cushions, even china. One of the trunks is a wedding present, much to her fiancés surprise and disappointment. For where he comes from, "a trunk was what you went out and bought, when you needed it. No passing it off as a present" (256). He comes from an affluent family and the cultural difference between them is often underscored. As one can expect, the trunk's contents are never used or displayed in the couple's new house in Vancouver. The presents would only become a cause for embarrassment and shame on the part of the narrator. She, however, will not be able to escape feelings of shame.

In "Deterritorializations: The Rewriting of Home and Exile in Western Feminist Discourse," Caren Kaplan works within and against the constructions of "deterritorialization" - interpreted as the "moment of alienation and exile in language and literature" with the aim of describing "a new terrain, a new location, in feminist politics." This deterritorialization, or becoming minor, requires that "[w]e must leave home, as it were, since our homes are often the sites of racism, sexism, and other damaging social practices. Where we come to locate ourselves in terms of our specific histories and differences must be a place with room for what can be salvaged from the past and what can be made anew" (187).

At the very end of the story "Home" there is an episode that is salvaged from the narrator's past and that occurred during, as she words it, "the worst winter of my childhood, which was 1935" (315). The episode is focused on the barn and the land outside of it. In her mind she pictures her father milking the cow that will eventually die from the cold, the land outside that will be frozen, bearing no crops, and herself "sitting on the first or second step watching [her] father milk the black-and-white cow" (314). It is an image of reflective nostalgia which, according to Boym, "does not pretend to rebuild the mythical place called home" (50). The home to which the narrator has returned has just been renovated and gentrified. This defamiliarization and sense of distance drive her to tell her story of the relationship between past, present and future. Through such longings the nostalgic narrator discovers that the past is not merely that which doesn't exist anymore; instead the past erupts in the present moment in unexpected ways. As a result, the past opens up a multitude of potentialities and "possibilities of historic development" since "reflective nostalgia has a capacity to awaken multiple planes of consciousness" (Boym 50). The modern nostalgic realizes that the journey in itself is what matters. Homecoming in this case does not imply a recovery of identity; to quote Boym again, a "modern nostalgic can be homesick and sick of home, at once" (50). The narrator's recollection of that scene in and outside the barn, as Caren Kaplan suggests, is suggestive of 
a new terrain, a new location, in feminist poetics. Not a room of one's own, not a fully public or collective self, not a domestic realm - it is a space of the imagination, which allows for the inside, the outside, and the liminal elements in between. Not a romanticized pastoral nor a modernist urban utopia - [the] garden is the space where writing occurs without loss or separation. (197-8)

Eleonora RAO

University of Salerno, Italy

\section{Works Cited}

Arendt, Hannah. The Human Condition. Chicago: Chicago UP, 1998.

Boym, Svetlana. The Future of Nostalgia. New York: Basic, 2001.

Bachelard, Gaston. The Poetics of Space. Trans. Maria Jolas. Boston: Beacon Press, 1969. Trans. of La Poétique de l'Espace. Paris : PUF, 1958.

Charman, Caitlin. "'Secretly Devoted to Nature': Place Sense in Alice Munro's The View from Castle Rock." Critical Insights: Alice Munro. Ed. Charles May. Ipswich, MA: Salem P, 2013. 259-75.

Deleuze, Gilles, and Felix Guattari. A Thousands Plateaus. Capitalism and Schizophrenia. Trans. Brian Massumi. London: Continuum, 1987. Trans. of Mille plateaux, volume 2 of Capitalisme et schirophrénie. Paris: Minuit, 1980.

Freud, Sigmund. The Uncanny. 1919. London: Penguin, 2003.

Hutchinson, Lorna. "Uncovering the Grotesque in Fiction by Alice Munro and Gabrielle Roy." Studies in Canadian Literature 33.1 (2008): 187-210.

Kaplan, Caren. "Deterritorializations: The Rewriting of Home and Exile in Western Feminist Discourse." Cultural Critique 6 (Spring 1987): 187-98.

Lowenthal, David. "Past Time, Present Place: Landscape and Memory." Geographical Review 65.3 (1975): 1-36.

Lessing, Doris. To Room Nineteen. New York: Vintage Books, 1980.

Marangoly George, Rose. The Politics of Home: Postcolonial Relocations and Twentieth-Century Fiction. Cambridge, UK: Cambridge UP, 1996.

Mars-Jones, Adam. Review of Alice Munro, The View from Castle Rock. The Observer 5 Nov. 2006. http://www.theguardian.com/books/2006/nov/05/fiction.features. Consulted 23 April 2015.

Martin, Biddy, and Chandra Talpade Mohanty. "What's Home Got to Do with It?" Feminist Studies, Critical Studies. Ed. Teresa De Lauretis. Bloomington: Indiana UP, 1986. 191-212.

McGilL, Robert. "Somewhere I've Been Meaning to Tell You: Alice Munro's Fiction of Distance." Journal of Commonwealth Literature 37.1 (2002): 9-29.

—. "Where do you think you are? Alice Munro's Open Houses." Mosaic 35.4 (2003): 103-120.

Munro, Alice. Dance of the Happy Shades. 1968. New York: Vintage, 1998.

—. Who Do You Think You Are? 1978. Toronto: Penguin, 1991.

—. Hateship, Friendship, Courtship, Marriage. Toronto: McClelland \& Stewart, 2001.

—. The View from Castle Rock. 2006. London: Vintage, 2007.

Porteous, Douglas J. “Home: The Territorial Core.” Geographical Review 66.4 (Oct. 1976): 383-90.

RAO, Eleonora. "The Stranger's Time is a Moving Train, a Plane in Flight: Alice Munro's étranger." Time and the Short Story. Ed. Maria Teresa Chialant, and Marina Lops. Bern: Peter Lang, 2012. 211-24.

SAID, Edward. Representations of the Intellectual. New York: Vintage, 1996.

—. The World, The Text and The Critic. Cambridge, MA: Harvard UP, 1983.

ShkLovsky, Viktor. Theory of Prose. 1925. Champaign, IL: Dalkey Archive P, 1991.

West-Pavlon, Russell. Space in Theory: Kristeva, Foucault, Deleure. Amsterdam: Rodopi, 2009.

Yeager, Patricia. "Narrating Space." The Geography of Identity. Ed. Patricia Yeager. Ann Arbor: Michigan UP, 1996. 1-39. 